\title{
Early-age behavior of blast-furnace slag cement pastes produced with carbon nanotubes grown directly on clinker
}

\section{Comportamento nas primeiras idades de pastas produzidas com cimento portland de alto forno fabricado com nanotubos de carbono crescidos diretamente sobre o clínquer}

P. A. SOARES a palomaassissoares@gmail.com https://orcid.org/0000-0002-0688-9934

A. Z. BENEDETTI alicez.benedetti@gmail.com https://orcid.org/0000-0001-7014-4876

T. C. SOUZA tarcizo.cruz@ctnano.org https://orcid.org/0000-0001-6437-0009

J. M. CALIXTO a imfcalixto@gmail.com https://orcid.org/0000-0003-2828-0967

L. O. LADEIRA a

loladeira@gmail.com https://orcid.org/0000-0002-4935-6070

\begin{abstract}
Carbon nanotubes are a promising material to solve the low tensile strength and ductility of Portland cement-based materials. Carbon nanotubes (CNTs) synthesized directly on cement clinker particles can also reduce production costs and help dispersion. In this scenario, this paper analyzes the fresh state rheological behavior, as well as the initial hydration period of blast-furnace slag (Brazilian CP III 40 RS) cement pastes produced with CNTs grown directly on clinker. CP III 40 RS was selected since it is one of the most used cement by the construction industry in Brazil. Cement pastes containing $0.1 \%$ and $0.3 \%$ of CNTs with respect to cement content were compared with CNT-free pastes. No chemical admixtures were used as a dispersant in all cases. The yield stress, plastic viscosity, temperature profile and evolved accumulated heat during the initial hydration period as well as setting times are the properties investigated. The results show that the addition of CNTs does not alter the rheological behavior of the cement pastes considering the employed concentrations, although the yield stress values were larger. The presence of CNTs in the cement pastes did not change the evolved accumulated heat during the first 72 hours of the hydration period.
\end{abstract}

Keywords: carbon nanotubes, blast-furnace slag cement pastes, fresh state rheological behavior, hydration heat, setting times.

\section{Resumo}

Nanotubos de carbono são elementos promissores para melhorar a pequena resistência à tração e a dutilidade de materiais a base de cimento Portland. Nanotubos de carbono (NTC) sintetizados diretamente sobre o clínquer de cimento podem também reduzir custos de produção e melhorar a dispersão destes na matriz. Neste cenário, este artigo analisa o comportamento reológico no estado fresco, bem como o período inicial de hidratação de pastas produzidas com cimento Portland de alto forno (CP III 40 RS) contendo NTC sintetizados diretamente sobre o clínquer. O CP III 40 RS foi selecionado, pois é um dos cimentos mais utilizados pela indústria da construção civil no Brasil. As pastas de cimento contendo $0,1 \%$ e $0,3 \%$ das NTC em relação a massa de cimento foram comparadas com pastas sem nanotubos. Nenhum aditivo foi usado como dispersante em todos os casos. A tensão de escoamento, a viscosidade plástica, o perfil térmico e o calor acumulado durante o período inicial de hidratação, bem como os tempos de pega são as propriedades investigadas. Os resultados mostram que a adição de NTC não altera o comportamento reológico das pastas de cimento considerando as concentrações empregadas, embora os valores da tensão de escoamento terem sido maiores. A presença de NTC nas pastas de cimento não alterou o calor acumulado durante as primeiras 72 horas do período de hidratação.

Palavras-chave: nanotubos de carbono, cimento Portland de alto-forno, pastas de cimento, comportamento reológico, calor de hidratação, tempos de pega. 


\section{Introduction}

Portland cement composites are the largest consumed construction materials worldwide. Among the reasons for this fact are the availability of raw materials and excellent compressive behavior. On the other hand, tensile characteristics of cementitious materials are poor due to their low tensile strength and brittle behavior. Recent investigations showed that the poor tensile behavior of cement-based materials is partly due to macroscopic defects (pores) and partly to the innate properties of calcium silicate hydrate $(\mathrm{C}-\mathrm{S}-\mathrm{H})$, the main constituent of hardened cement paste.

Carbon nanomaterials, such as carbon nanotubes (CNTs) and graphene, have recently attracted tremendous scientific interest due to the remarkable and useful properties, such as exceptional tensile strength, elastic modulus, and electrical and thermal conductivity [1, 2]. These materials are promising candidates for next-generation high-performance structural and multi-functional cement composites $[3,4,5,6,7]$.

Carbon nanotubes (CNTs) are graphene sheets rolled up to form cylinders or tubes. A single-walled CNT looks like a single sheet rolled up into a tube, while multi-walled CNTs look like multiple sheets rolled into a series of tubes, one inside the other. A single-walled CNT is typically 1-3 nm in diameter and a micrometer or more long. Multi-walled CNTs typically range in diameter from 10 to $40 \mathrm{~nm}$ but have the same length as the single-walled variety [8, 9]. According to Santra et al. [10], CNTs behave as one-dimensional materials. In addition, they present tensile strength and Young's modulus values ten times greater than steel and a density five times smaller [8,9]. Consequently, CNTs have very high

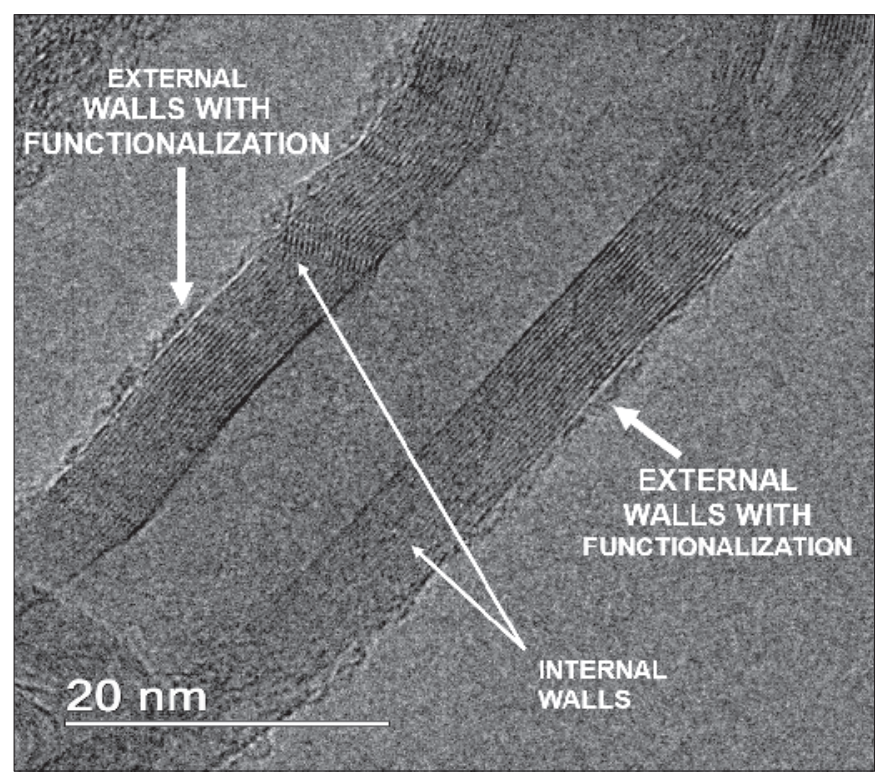

\section{Figure 1}

Transmission electron microscopy image of CNT grown directly on the cement clinker aspect ratios (length/diameter ratio) and can be distributed widely and densely at the microscopic scale yet covering longer lengths. These characteristics can be used in cement composites to bridge cracks and restrict them from increasing which can essentially create a new generation of crack-free cement materials [8, 9].

Many procedures have been used to promote an adequate dispersion of CNTs in cement-based composites [8, 9, 11]. However, these routes are not always compatible with the common processes used by the construction industry. In this context, a way that has proven viable is the CNTs synthesis in situ, directly on the clinker particle. This process, patented by Ladeira et al. [12], promotes a natural dispersion of CNTs making their application in the context of the construction industry more adequate. Investigations, that use this technology, show significative results in terms of gains in compressive and tensile strength $[13,14,15]$.

In continuation of previous studies [13, 14, 15], the goal of this work is to present the results of the fresh state rheological behavior as well as of the initial hydration period of blast furnace slag (Brazilian CP III 40 RS) Portland cement pastes produced with carbon nanotubes grown directly on clinker. The yield stress, plastic viscosity, temperature profile and evolved accumulated heat during the initial hydration period as well as setting times are the properties investigated. Cement pastes containing $0.1 \%$ and $0.3 \%$ of CNTs with respect to cement content were compared with CNT-free pastes. No chemical admixtures were used as a dispersant in all cases. CP III 40 RS cement was selected since it is one of the most used cement by the construction industry in Brazil.

\section{Experimental methodology}

\subsection{Materials}

According to Santra et al. [10], the effective reinforcement of cement with CNTs requires the consideration of the following factors: (1) the kind of CNT used and the aspect ratio; (2) the chemical functionality of the outer CNT wall; (3) the technique of dispersion in the cement matrix and (4) the workability of the fresh cement composite paste.

In this study, multi-walled carbon nanotubes (CNTs) were grown directly on cement clinker in a continuous process (Ladeira et al. [12]) at the Technological Center for Nanomaterials and Graphene (CTNano) of the Federal University of Minas Gerais, Belo Horizonte, Brazil. Ground iron oxide, a residue from mining exploration, was employed as a catalyst and a hydrocarbon gas as a carbon precursor in the chemical vapor deposition (CVD) process. This way, the produced CNTs have a natural functionality due to the defects they present in their shapes and outer walls, which, in turn, leads to no need for chemical functionalization. Figure 1 is a transmission electron microscopy (TEM) image, which illustrates this natural functionality: CNT outer walls have defects, which can provide a chemical and 


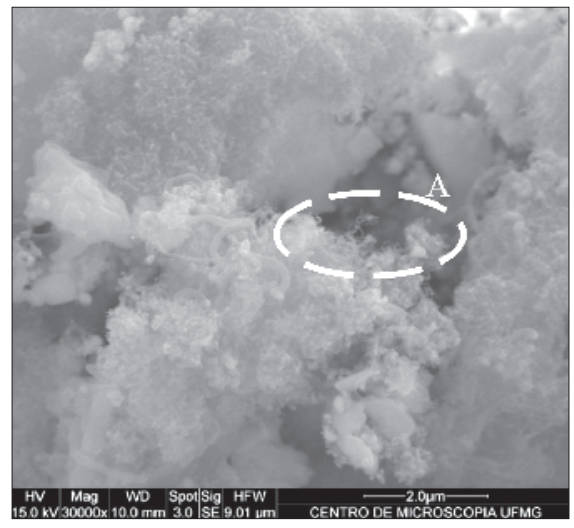

(a)

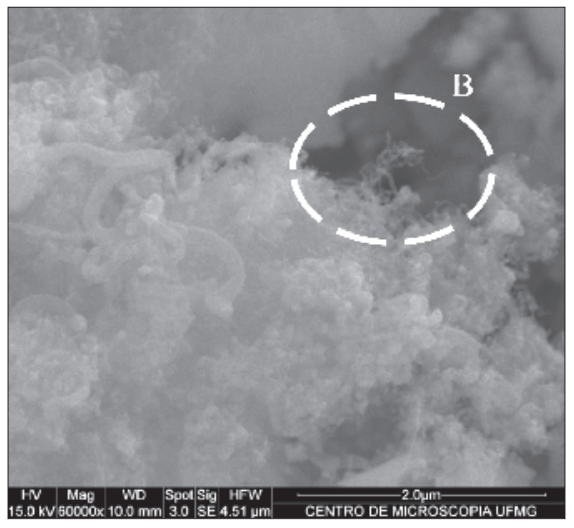

(b)

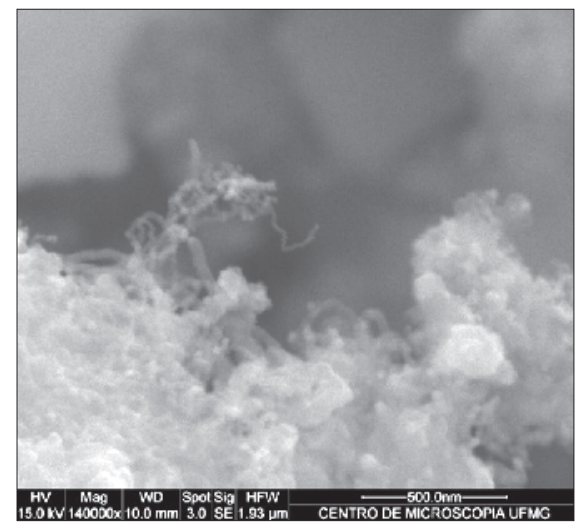

(c)

Figure 2

Scanning electron microscopy images of CNTs grown directly on the cement clinker

mechanical bond between the CNTs and the cement hydration products. The figure also shows that the CNTs are not perfectly straight. Thus, it is undoubtedly a much simpler, cheaper and lesser time-consuming way to produce functionalized CNTs to be used in cement composites. It also allows for large-scale production, which can be employed during cement manufacturing.

The maximum CNT length was in the order of tens of microns. The mean diameter of CNTs was between 15 and 40 $\mathrm{nm}$. Thus, the average CNT aspect ratio was approximately 1000. Figure 2 shows scanning electron microscopy (SEM) images of the CNTs grown directly onto the cement clinker. From the figure, one can see that CNTs are well distributed in the clinker particles and are polydisperse in terms of length and diameter. The nanostructured clinker contained approximately $10.5 \%$ of carbon nanotubes by weight, as determined by thermogravimetric analysis, as shown in Figure 3.

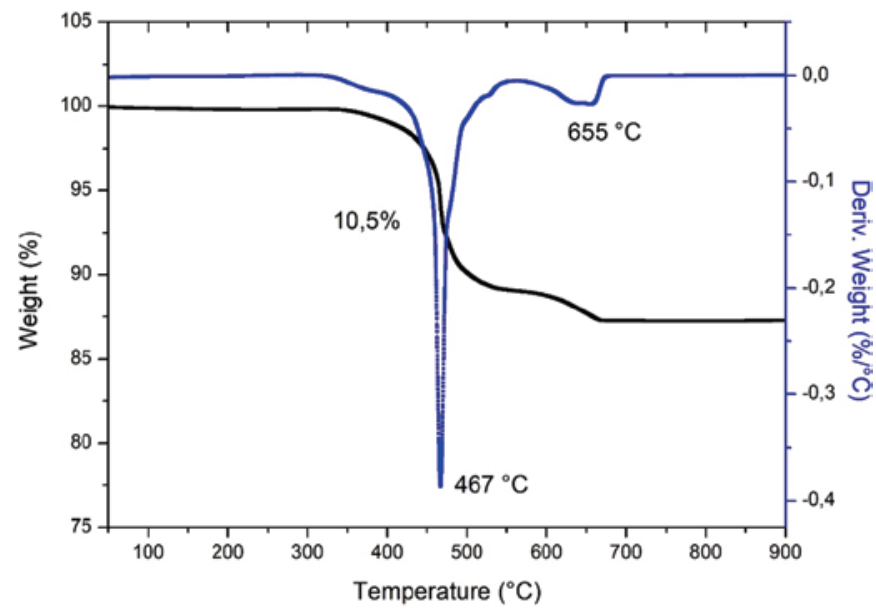

\section{Figure 3}

Thermo-gravimetrical analysis of the nanostructured clinker
Table 1 shows the physical and chemical characteristics of the Brazilian CP III 40 RS (blast-furnace slag) Portland cement used in these studies. These results were obtained from tests performed at InterCement Cement Plant in Pedro Leopoldo, Brazil.

\subsection{Preparation of the cement pastes}

The cement pastes were prepared at the CTNano laboratories in Belo Horizonte. The ambient temperature and relative humidity were monitored around $24 \pm 2^{\circ} \mathrm{C}$ and $30 \%-50 \%$ respectively.

\section{Table 1}

Physical and chemical characteristics of Brazilian CP III 40 RS Portland cement

\begin{tabular}{|c|c|c|}
\hline $\begin{array}{c}\text { Physical } \\
\text { characteristics }\end{array}$ & Sample & $\begin{array}{c}\text { Standard } \\
\text { requirements } \\
\text { (Brazilian } \\
\text { NBR-5735) }\end{array}$ \\
\hline $\begin{array}{c}\text { Residue in sieve } \\
75 \mu \mathrm{m}\end{array}$ & $0.467 \%$ & $\leq 8.0 \%$ \\
\hline Blaine finesse & $4642 \mathrm{~cm}^{2} / \mathrm{g}$ & - \\
\hline $\begin{array}{c}\text { Chemical } \\
\text { characteristics }\end{array}$ & Sample & $\begin{array}{c}\text { Standard } \\
\text { requirements } \\
\text { (Brazilian } \\
\text { NBR-5735) }\end{array}$ \\
\hline Fire loss & $3.47 \%$ & $\leq 4.5 \%$ \\
\hline Insoluble residue & $1.40 \%$ & - \\
\hline $\mathrm{SO}_{3}$ & $2.38 \%$ & $\leq 4.0 \%$ \\
\hline $\mathrm{MgO}$ & $3.43 \%$ & - \\
\hline $\mathrm{SiO}_{2}$ & $24.09 \%$ & - \\
\hline $\mathrm{Al}_{2} \mathrm{O}_{3}$ & $6.36 \%$ & - \\
\hline $\mathrm{Fe}_{2} \mathrm{O}_{3}$ & $3.30 \%$ & - \\
\hline $\mathrm{CaO}$ & $54.81 \%$ & - \\
\hline $\mathrm{Na}_{2} \mathrm{O}$ & $0.14 \%$ & - \\
\hline $\mathrm{K}_{2} \mathrm{O}$ & $0.67 \%$ & - \\
\hline
\end{tabular}


Table 2

Cement paste denomination and corresponding mix proportion used for a 0.6 - liter volume

\begin{tabular}{ccccc}
\hline $\begin{array}{c}\text { Cement paste } \\
\text { denomination }\end{array}$ & $\begin{array}{c}\text { Cement* } \\
(\mathbf{g})\end{array}$ & $\begin{array}{c}\text { Water } \\
(\mathrm{g})\end{array}$ & $\begin{array}{c}\text { Nanostructured clinker } \\
(\mathrm{g})\end{array}$ & $\begin{array}{c}\text { Carbon nanotubes } \\
(\mathbf{g})\end{array}$ \\
\hline Reference & 837 & 335 & - & - \\
CNTO1 & 831.4 & 335 & 5.6 & 0.84 \\
CNTO3 & 820.2 & 335 & 16.8 & 2.52 \\
\hline * Brazilin
\end{tabular}

* Brazilian CP III 40 RS (blast-furnace slag) cement

The CNT cementitious material containing the anhydrous cement and the nanostructured clinker was first mixed together in a Y-type mixer. The mixing time was 20 minutes. This procedure was used to disperse and homogenize the nanostructured clinker into the pure cement.

The volume of each cement paste batch was always equal to 0.6 liters. For the production of this volume, the amount of cement used in each composition was always equal to 837 grams and the water/cement ratio equal to 0.4 . The CNTs synthesized directly on cement clinker ratio corresponded to $0.1 \%$ and $0.3 \%$ of the binder weight (bwoc). This amount of CNTs was based on results obtained by Souza [16]. No chemical admixtures were used as a dispersant in all cases. Three different pastes were prepared and tested. Table 2 shows the mix proportion of each paste as well as its corresponding denomination, which will be referred to throughout this paper.

A Chandler Engineering ${ }^{\mathrm{TM}}$ mixer was employed to prepare the cement pastes. The dry cementitious material was added to the water evenly through the central opening of the lid of the mixer up to 15 seconds. In this time interval, the mix rotation was $5000 \mathrm{rpm} \pm 200 \mathrm{rpm}$. After that, the lid was completely closed and the stirring process continued for another 15 seconds at the same rotation. Then the paste was manually agitated with a stick for approximately $15 \mathrm{sec}-$ onds. Finally, the paste was stirred for another 30 seconds at a rotation of $5000 \mathrm{rpm} \pm 200 \mathrm{rpm}$.

\subsection{Rheological behavior tests}

The rheological behavior tests were conducted using a

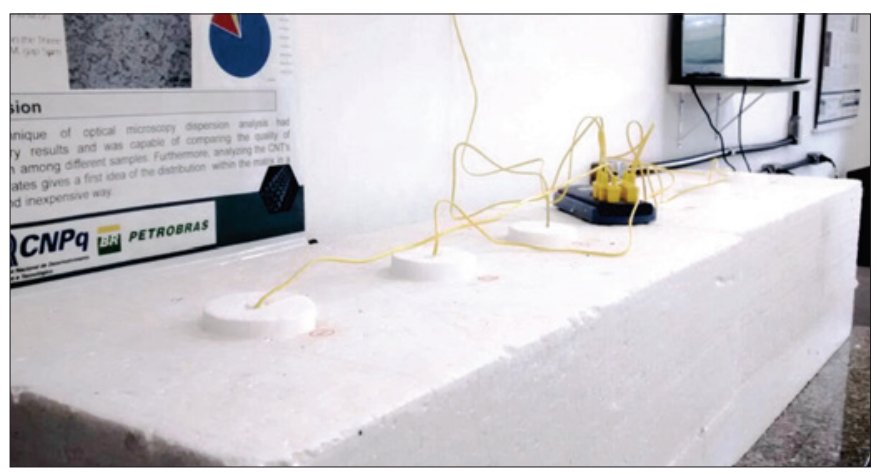

Figure 4

Details of the semi-adiabatic chambers made of expanded polystyrene blocks rheometer RHEOTEST (Medingen $\mathrm{GmbH}$ ) totally controlled by software that monitors and analyzes the obtained data. Right after the cement pastes were mixed, they were placed inside a cup, which was inserted into the rheometer to start the rheological behavior tests. The shear rate was applied from $0.6 \mathrm{~s}^{-1}$ to $100 \mathrm{~s}^{-1}$ for 120 seconds and then back from $100 \mathrm{~s}^{-1}$ to $0.6 \mathrm{~s}^{-1}$ for another 120 seconds (Soares, [17]). The downslope curve data was employed in the calculation of the rheological parameters. Four specimens were used for each cement paste composition. The apparent viscosity, shear stress and shear rate of each cement paste with and without CNTs were measured by the rheometer. The yield stress $\left(\mathbf{t}_{0}\right)$ and plastic viscosity $\left(\mathbf{m}_{\mathrm{p}}\right)$ were then calculated using the Bingham and Modified Bingham models.

Bingham is the most widely used model to evaluate the yield stress and plastic viscosity of cement pastes (Papo, [18]). It corresponds to a mathematical equation, which is linear (Equation [1]) and is a function of the yield shear stress $\mathbf{t}_{0}$ and the plastic viscosity $m_{p}$. In general, the Bingham model does not fit well the nonlinear portion of the flow curve at low shear rates. In order to overcome this fact, the modified Bingham model is used, which corresponds to a secondorder polynomial (Equation [2]) where $\boldsymbol{c}$ is a fitting regression constant. In both of these models, $\mathrm{T}$ is the shear stress while $\ddot{Y}$ is the shear rate.

$\boldsymbol{\tau}=\boldsymbol{\tau}_{0}+\boldsymbol{\mu}_{\boldsymbol{p}} \ddot{\mathrm{Y}}$

$\boldsymbol{\tau}=\boldsymbol{\tau}_{0}+\boldsymbol{\mu}_{p} \ddot{\mathrm{Y}}+c \ddot{\mathrm{Y}}^{2}$

\subsection{Heat of hydration}

According to ASTM C1753 [19], non-conventional differential thermal analysis (NCDTA) can be employed to evaluate the heat of hydration of hydraulic cementitious mixtures, through the measurement of the temperature difference between a sample and an inert reference, when both are submitted to the same environmental conditions. In this case, the system operates semi-adiabatically and the temperature difference is measured due to the exothermal effects promoted by the spontaneous cement hydration reactions. ASTM C1753 still prescribes that the inert material temperature throughout the test period is of paramount importance since this tends to account for the effects of the change of the ambient temperature during the measurement period, as well as possible interference from a sample to the other. This way it specifies that the inert reference has a maximum 
Table 3

Specific heat capacity of each component of the cement paste

\begin{tabular}{cc}
\hline Component & $\begin{array}{c}\text { Specific heat capacity } \\
\left(\mathrm{T}_{\text {in }}^{\circ} \mathrm{C}\right)\end{array}$ \\
\hline Brazilian type III 40 RS cement & $\mathrm{C}_{\mathrm{c}}=0.0045 . \mathrm{T}+0.4807$ \\
Nanostructured clinker & $\mathrm{C}_{\mathrm{nc}}=0.0035 . \mathrm{T}+0.5509$ \\
Water & $\mathrm{C}_{\mathrm{w}}=4.18 \mathrm{~J} /\left(\mathrm{g} .{ }^{\circ} \mathrm{C}\right)$ \\
\hline
\end{tabular}

variation of $3^{\circ} \mathrm{C}$ throughout the test period. This method was used in this investigation.

The semi-adiabatic chambers consisted of two blocks made of expanded polystyrene. Each block had dimensions of $93.5 \mathrm{~cm}$ (length) $\times 42.5 \mathrm{~cm}$ (width) $\times 36 \mathrm{~cm}$ (height). In each block, three cylindrical holes were drilled where the aluminum cans surrounded by Styrofoam cups were placed. Each cup had an expanded polystyrene lid with a small hole from which the leads from the thermocouples passed through as shown in Figure 4 (Benedetti [20]).

Right after the cement pastes were mixed, they were placed inside the aluminum cans, capped and then inserted into the expanded polystyrene blocks. Each can contain 0.2 liters of each cement paste batch. In a certain can was placed an inert reference material, which in this case consisted of sand and water in the same amount of cement and water used in the pastes. A thermocouple was placed inside the fresh cement paste or the reference material. This way it measured the reference material or the cement paste temperature. Ten specimens were used for each cement paste composition. The temperature data acquisition was done by a controller device connected to a computer. The data was collected during the first 72 hours of hydration, every 30 seconds.

The specific heat capacity, in the range from 10 to $80^{\circ} \mathrm{C}$, of the raw materials used in the cement pastes, was determined by differential scanning calorimetry (DSC) analysis. These values are presented in Table 3 for each component. For each cement paste composition, the cumulative evolved heat, in arbitrary units, was calculated according to the equations presented in Table 4.

The consistency change of the cement pastes with respect to time was evaluated employing the Vicat analysis, performed according to Brazilian Standard Method NBR NM 65 [21].

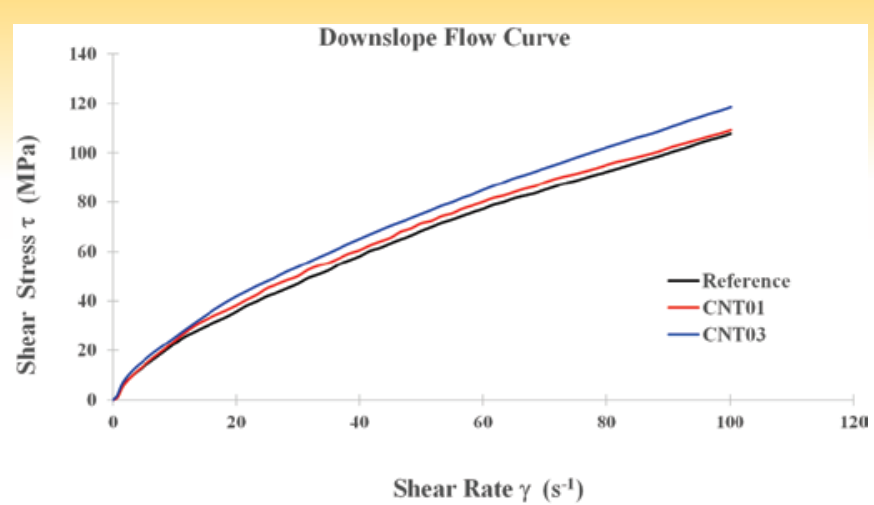

Figure 5

Shear stress versus shear rate relationships for the investigated cement pastes

The procedure measures the Vicat needle penetration in the pastes as their setting processes occur. The only difference in this case with respect to NBR NM 65 specifications was the water/cement ratio: 0.4 was used since this was the value adopted in the NCDTA evaluation. This way the initial and final setting times could be correlated with the evolved accumulated heat during the hydration period. Three specimens for each cement paste composition were used.

\section{Results and discussion}

Figure 5 presents the most representative downslope flow curve for each of the three cement paste compositions (Reference, CNT01, and CNT03). The flow curves are almost equal for both the Reference and CNT01 cement pastes. For the CNT03 composition, there is a difference with respect to the other two: for the same shear rate, the corresponding yield stress is larger.

The calculated values of mean yield stress and plastic viscosity using the Bingham and Modified Bingham models are shown in Table 5 and Figure 6 . The comparison between both mathematical models shows that for all pastes the modified Bingham, which fits better the nonlinear portion of the flow curve at low shear rates, has smaller values for the yield stress and larger values for the plastic viscosity. The addition of CNT leads to larger yield stress values with respect

\section{Table 4}

Cumulative evolved heat for each cement paste composition used for a 0.2 - liter volume

\begin{tabular}{cc}
\hline Cement paste denomination & Cumulative evolved heat (arbitrary units-a.u.) \\
\hline Reference & $[279 \cdot(0.0045 \cdot T+0.4807)+112 \cdot 4.18)] \cdot \Delta T^{*}$ \\
CNTO1 & {$[277.1 \cdot(0.0045 \cdot T+0.4807)+1.9 \cdot(0.0035 \cdot T+0.5509)+112 \cdot 4.18] \cdot \Delta T^{*}$} \\
CNTO3 & {$[273.4 \cdot(0.0045 \cdot T+0.4807)+5.6 \cdot(0.0035 \cdot T+0.5509)+112 \cdot 4.18] \cdot \Delta T^{*}$} \\
\hline${ }^{*} \Delta T=\left(T_{\text {sample }}-T_{\text {ther material }}\right)\left(\right.$ in $\left.{ }^{\circ} \mathrm{C}\right)$ &
\end{tabular}

\section{Table 5}

Rheological parameters for the three cement compositions

\begin{tabular}{ccccccc}
\hline \multirow{2}{*}{$\begin{array}{c}\text { Cement paste } \\
\text { denomination }\end{array}$} & $\begin{array}{c}\text { Yield stress } \\
\text { (Pa) }\end{array}$ & $\begin{array}{c}\text { Bingham model } \\
\text { Plastic viscosity } \\
\text { (Pa.s) }\end{array}$ & $\begin{array}{c}\text { Regression } \mathbf{r}^{2} \\
\text { value }\end{array}$ & $\begin{array}{c}\text { Yield stress } \\
(\text { Pa) }\end{array}$ & $\begin{array}{c}\text { Plastic viscosity } \\
\text { (Pa.s) }\end{array}$ & $\begin{array}{c}\text { Regression } \mathbf{r}^{2} \\
\text { value }\end{array}$ \\
\hline Reference & $18.2 \pm 1.24$ & $0.99 \pm 0.06$ & 0.988 & $10.2 \pm 0.92$ & $1.39 \pm 0.02$ & 0.999 \\
CNTO1 & $20.8 \pm 1.12$ & $0.98 \pm 0.07$ & 0.984 & $11.4 \pm 0.58$ & $1.46 \pm 0.03$ & 0.999 \\
CNTO3 & $21.3 \pm 1.81$ & $1.01 \pm 0.05$ & 0.988 & $12.4 \pm 1.12$ & $1.47 \pm 0.03$ & 0.999 \\
\hline
\end{tabular}


Early-age behavior of blast-furnace slag cement pastes produced with carbon nanotubes grown directly on clinker
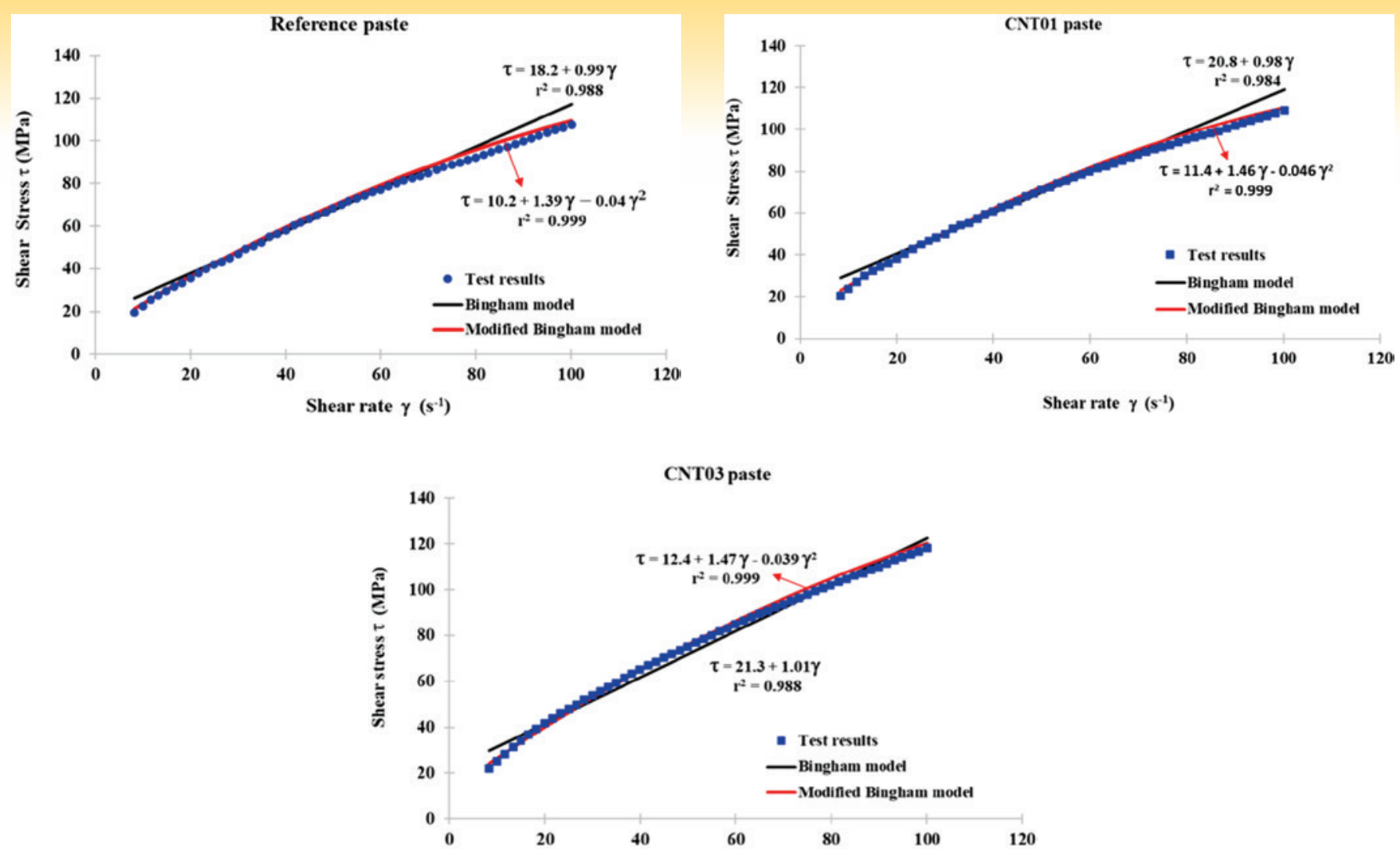

Shear rate $\gamma\left(\mathbf{s}^{-1}\right)$

\section{Figure 6}

Bingham and modified Bingham model for the investigated cement pastes

to the reference pastes in both models. On the other hand, no change was observed in the plastic viscosity of all pastes. This way, comparative analysis of these results shows the equivalence of these rheological parameters. The modified Bingham model represents much better the observed behavior as shown in Figure 6 for all pastes.

It has been reported in the literature that like any most nanomaterials, the workability of cement paste is often reduced with the addition of CNTs due to their large surface area (Kowald and Trettin [22]). The results obtained in this study show otherwise: with CNTs directly grown on clinker, no significant changes were found in the rheological behavior of the cement pastes.

Figure 7 shows the thermal profile versus time relationships for the most representative specimen of each cement paste composition. The analysis of the thermal profiles indicates

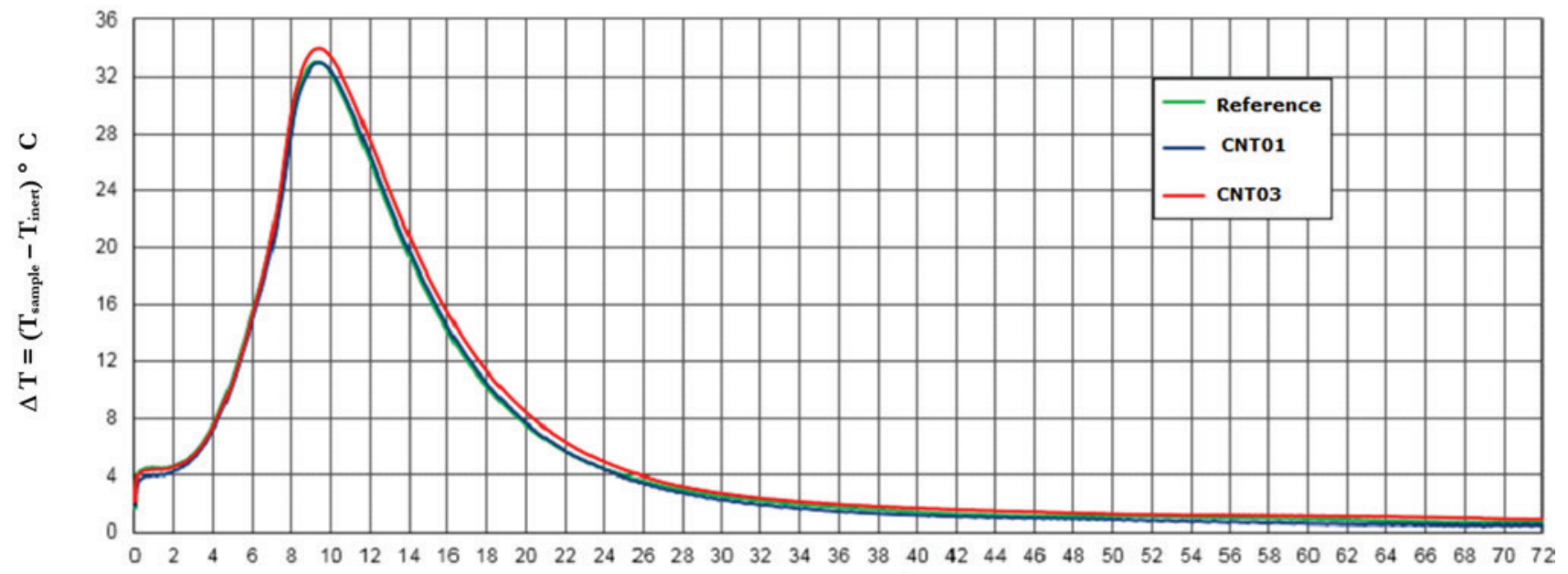

Time (hours)

Figure 7

Representative thermal profiles of the cement pastes 


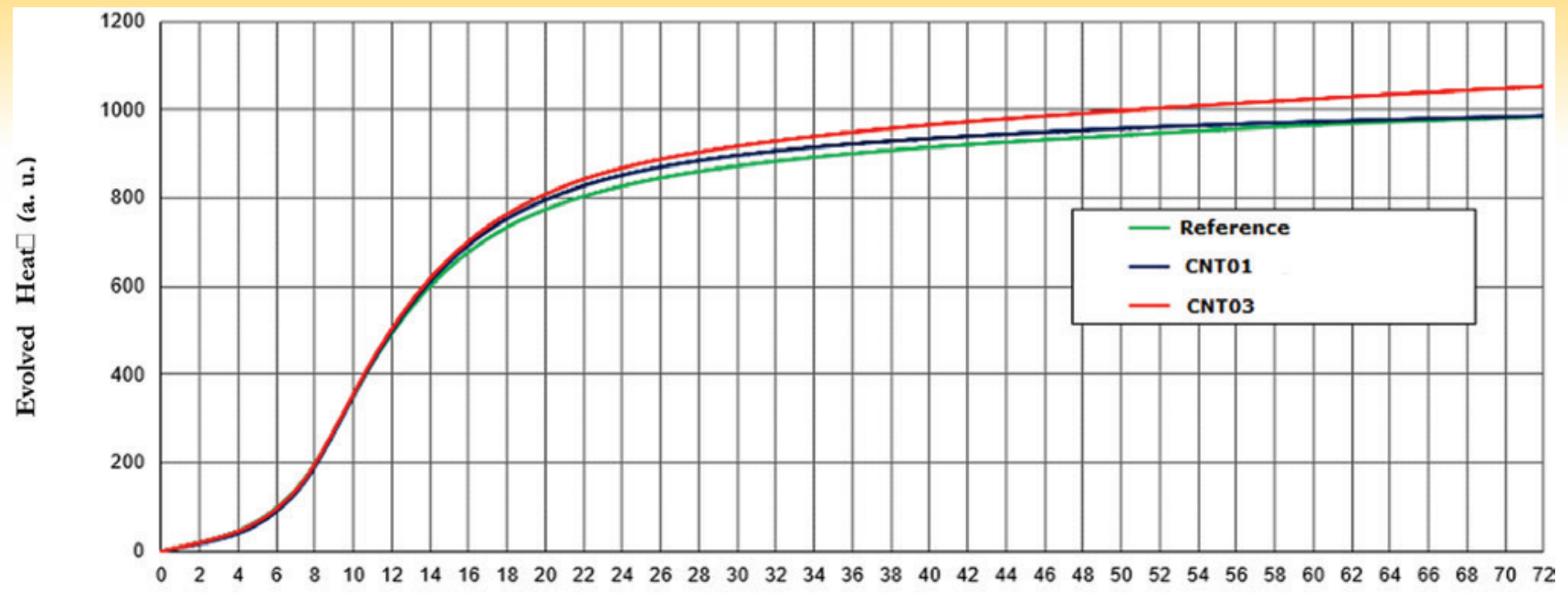

Time (hours)

\section{Figure 8}

Evolved accumulated heat (a. u.) of the cement pastes

that they are very similar and that the main peak of cement paste with carbon nanotubes (CNT01 and CNT03) occurs practically at the same time in comparison with the reference without CNTs. Therefore, the effect of the presence of CNTs on the thermal profiles of cement pastes made with cement CPIII-40 RS was not significant.

The evolved heat versus time relationships for the most representative of each type of cement paste investigated are presented in Figure 8 . Table 6 shows the average accumulated heat values with the respective standard deviation values of the three different cement pastes up to 24 and 72 hours. The analysis of these results indicates that the addition of $0.1 \%$ and of $0.3 \%$ of CNT on the accumulated heat of pastes produced with CPIII- 40 RS was not significant up to 72 hours. The differences between the values are within $10 \%$ of each other.

\section{Table 6}

Evolved accumulated heat, in arbitrary units, for each cement paste composition

\begin{tabular}{ccc}
\hline $\begin{array}{c}\text { Cement paste } \\
\text { denomination }\end{array}$ & $\begin{array}{c}\text { Evolved heat up } \\
\text { to 24 hours } \\
\text { (a.u.) }\end{array}$ & $\begin{array}{c}\text { Evolved heat up } \\
\text { to } \mathbf{7 2} \text { hours } \\
\text { (a.u.) }\end{array}$ \\
\hline Reference & $823 \pm 14$ & $969 \pm 30$ \\
CNTO1 & $845 \pm 18$ & $984 \pm 19$ \\
CNTO3 & $864 \pm 24$ & $1049 \pm 34$ \\
\hline
\end{tabular}

In addition to Vicat analysis, a procedure, developed by $\mathrm{HU}$ et. al [23], was employed to evaluate the initial and the final setting times. The methodology is based on the first derivative of the temperature profile along the time. According to

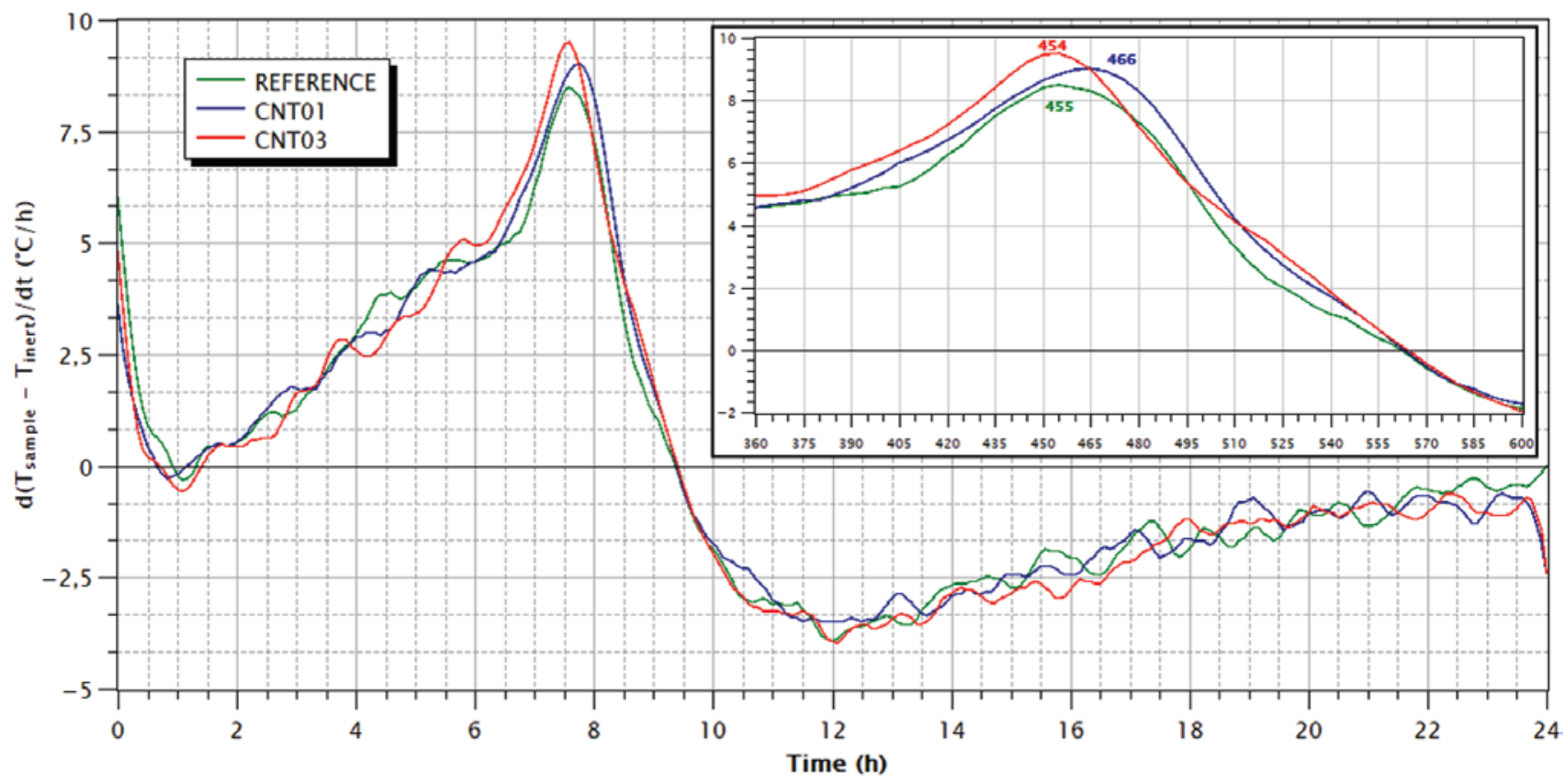

Figure 9

First derivative of the temperature profile versus time relationships for each type of cement paste investigated 


\section{Table 7}

Vicat analysis: average initial and final setting times and corresponding evolved accumulated heat for each cement paste composition

\begin{tabular}{ccccc}
\hline $\begin{array}{c}\text { Cement paste } \\
\text { denomination }\end{array}$ & $\begin{array}{c}\text { Average initial } \\
\text { setting time } \\
\text { Vicat analysis } \\
\text { (min) }\end{array}$ & $\begin{array}{c}\text { Corresponded } \\
\text { accumulated heat } \\
\text { (a. u.) }\end{array}$ & $\begin{array}{c}\text { Average final } \\
\text { setting time } \\
\text { Vicat analysis } \\
\text { (min) }\end{array}$ & $\begin{array}{c}\text { Corresponded } \\
\text { accumulated heat } \\
\text { (a. u.) }\end{array}$ \\
\hline Reference & $336 \pm 1$ & $65 \pm 4$ & $370 \pm 5$ & $83 \pm 4$ \\
CNTO1 & $305 \pm 2$ & $68 \pm 4$ & $332 \pm 5$ & $91 \pm 5$ \\
CNTO3 & $297 \pm 3$ & $75 \pm 4$ & $345 \pm 8$ & $96 \pm 5$ \\
\hline
\end{tabular}

\section{Table 8}

First derivative procedure: average initial and final setting times and corresponding evolved accumulated heat for each cement paste composition

\begin{tabular}{ccccc}
\hline $\begin{array}{c}\text { Cement paste } \\
\text { denomination }\end{array}$ & $\begin{array}{c}\text { Average initial } \\
\text { setting time } \\
\text { First derivative analysis } \\
\text { (min) }\end{array}$ & $\begin{array}{c}\text { Corresponded } \\
\text { accumulated heat } \\
\text { (a. u.) }\end{array}$ & $\begin{array}{c}\text { Average final } \\
\text { setting time } \\
\text { First derivative analysis } \\
\text { (min) }\end{array}$ & $\begin{array}{c}\text { Corresponded } \\
\text { accumulated heat } \\
\text { (a. u.) }\end{array}$ \\
\hline Reference & $458 \pm 3$ & $174 \pm 4$ & $565 \pm 5$ & $306 \pm 8$ \\
CNTO1 & $469 \pm 4$ & $180 \pm 6$ & $568 \pm 5$ & $303 \pm 5$ \\
CNTO3 & $456 \pm 2$ & $170 \pm 7$ & $562 \pm 8$ & $308 \pm 4$ \\
\hline
\end{tabular}

$\mathrm{HU}$ et. al [23], the initial setting time is defined as the time when the first derivative reaches its highest value. At this point, the increase in the rate of heat generation is the fastest. After this initial setting time, the first derivative values start to decrease. The time when the first derivative drops to zero is defined as the calorimetry of the final setting time. This point corresponds to the time when the highest rate of hydration is achieved; after this point, the rate of hydration will be reduced. The most representative of the first derivative of the temperature profile versus time relationships for each type of cement paste investigated are presented in Figure 9. Closer detail of the initial and final setting times is also shown in the figure.

The average initial and final setting times, as well as, their corresponding evolved accumulated heat for each type of investigated cement paste are presented in Tables 7 and 8. Table 7 corresponds to the values determined according to the Vicat analysis, while in Table 8 the values were calculated from the first derivative of the temperature profile along the time.

The Vicat analysis, determined according to NBR NM 65 [21], indicates that the addition of CNTs in both contents reduced significantly the initial and final setting times of the cement pastes with respect to the reference. The initial and final setting times were reduced by $10 \%$ approximately for cement pastes containing CNTs with respect to the CNT-free paste. This difference in the setting times does not correlate well with the corresponding evolved accumulated heat: in the first 10 hours of the hydration period, the evolved accumulated heat is about the same for all cement pastes regardless of the presence or not of CNTs.

The analysis according to the first derivative of the temperature profile versus time shows otherwise. The initial and final setting times, as well as, their corresponding evolved accumulated heat are basically the same for all cement pastes. This indicates a good correlation between these parameters as should be expected. These results also reveal that the presence of CNTs made no difference in the first 72 hours of the cement hydration process.

The values of the initial and final setting times obtained with the Vicat analysis and the first derivative of the temperature profile along the time are significantly different. The values with the Vicat method are much smaller. This finding was also obtained by $\mathrm{HU}$ et. al [23]. This fact, as explained by $\mathrm{Hu}$, is due to the very different mechanisms and test setups in determining setting times. Vicat method is a physical procedure while the first derivative methodology is related to thermodynamics of the hydration process.

\section{Conclusions}

The goal of this work was to present the results of the earlyage behavior of blast furnace slag (Brazilian CP III 40 RS) Portland cement pastes produced with carbon nanotubes grown directly on clinker. This way, the produced CNTs have a natural functionality due to the defects they present in their shapes and outer walls. Thus, it is undoubtedly a much simpler, cheaper and lesser time-consuming way to produce functionalized CNTs to be used in cement composites. It also allows for large-scale production, which can be employed during cement manufacturing. CP III 40 RS cement was selected since it is one of the most used cement by the construction industry in Brazil. The yield stress, plastic viscosity, evolved accumulated heat, and the initial and final setting times of the cement pastes were the investigated characteristics. The main conclusions are:

1. The results show that the addition of CNTs in both contents $(0.1$ and $0.3 \%$ bwoc) does not alter the rheological 
behavior, although the yield stress values were larger. It has been reported in the literature that like any most nanomaterials, the workability of cement paste is often reduced with the addition of CNTs due to their large surface area. The results herein show otherwise, which indicates that with the procedure used in this investigation to include CNTs in cement pastes and the employed $\mathrm{CNT} /$ cement ratios no significant changes were found in the rheological behavior of the cement slurries.

2. All cement pastes presented a nonlinear behavior of the downslope flow curve at low shear rates. Due to this fact, the modified Bingham model represents much better this observed behavior.

3. The Vicat analysis indicates that the addition of CNTs in both contents reduced significantly the initial and final setting times of the cement pastes with respect to the reference. On the other hand, the results according to the first derivative of the temperature profile versus time show that the initial and final setting times, as well as, their corresponding evolved accumulated heat are basically the same for all cement pastes regardless of the presence or not of CNTs. This fact is due to the very different mechanisms and test setups in determining setting times. Vicat method is a physical procedure while the first derivative methodology is related to thermodynamics of the hydration process.

\section{Acknowledgments}

The authors would like to acknowledge the financial aid and invaluable support of CENPES/PETROBRAS, Intercement Brasil S/A, BNDES, FAPEMIG, CNPq, CAPES, INCT, and the Center of Microscopy at UFMG.

\section{References}

[1] DRESSELHAUS, M.S., DRESSELHAUS, G., EKLUNG, P.C., 1996, Science of Fullerenes and Carbon Nanotubes (USA), Elsevier Science Imprint, California, 〈http://www. academicpress.com〉. HUANG, X., QI, Y., BOEY, F., ZHANG, H., 2012, Graphene-based composites. Chemical Society Reviews, 41, p. 666-686, http://dx.doi.org /10.1039/c1cs15078b. LI, G.Y., WANG, P.M. and ZHAO, X., 2005, Mechanical behavior and microstructure of cement composites incorporating surface-treated multiwalled carbon nanotubes, Carbon, Vol. 43, pp. 1239-1245, doi:10.1016/j.carbon.2004.12.017. MAKAR, J.M. and CHAN, G.W., 2009, Growth of cement hydration products on single-walled carbon nanotubes, Journal American Ceramic Society Vol. 92, pp. 1303-1310, doi: 10.1111/j.15512916.2009.03055.x.

[5] MUSSO, S.; TULLIANI, J.-M.; FERRO, G. and TAGLIAFERRO, A., 2009, Influence of carbon nanotubes on the mechanical behavior of cement composites, Composites Science and Technology,
Vol. 69, pp. 1985-1990, doi:10.1016/j.compscitech.2009.05.002.

[6] KONSTA-GDOUTOS, M. S., METAXA, Z. S. and SHAH, S. P., 2010, Multi-scale mechanical and fracture characteristics and early-age strain capacity of high-performance carbon nanotube/ cement nanocomposites, Cement \& Concrete Composites, Vol. 32, pp. 110-115. doi:10.1016/j. cemconres.2010.02.015.

[7] KUMAR, S., KOLAY, P., MALLA, S., MISHRA, S., 2012. Effect of multiwall carbon nanotubes on mechanical strength of cement paste. J. Mater. Civil Eng. (ASCE) 24, 84-91. http://dx.doi.org/10.1061/ (ASCE)MT.1943-5533.0000350.

[8] RASHAD, A. M., 2017, Effect of carbon nanotubes ( CNTs ) on the properties of traditional cementitious materials, Construction and Building Materials., vol. 153, pp. 81-101. http://dx.doi.org/10.1016/j.conbuildmat.2017.07.089.

[9] REALES, O. M. and TOLEDO FILHO, R. D., 2017, A review on the chemical, mechanical and microstructural characterization of carbon nanotubescement based composites, Construction and Building Materials, vol. 154, pp. 697-710. http://dx.doi. org/10.1016/j.conbuildmat.2017.07.232.

[10] SANTRA, A., BOUL, P.J., PANG, X., 2012. Influence of nanomaterials in oil well cement hydration and mechanical properties. In: Proceedings of the SPE International Oilfield Nanotechnology Conference held in Noordwijk. Netherlands, 12-14 June, SPE 156937.

[11] S. PARVEEN, S. RANA, and R. FANGUEIRO, 2013, A review on nanomaterial dispersion, microstructure, and mechanical properties of carbon nanotube and nanofiber reinforced cementitious composites, Journal of Nanomaterials, pp. 1-19, http://dx.doi.org/10.1155/2013/710175

[12] LADEIRA, L. O.; SILVA, E. E.; OLIVEIRA, S.; LACERDA, R. G.; FERLAUTO, A. S.; ÁVILA E.; LOURENÇON, E., 2015, Large-scale production of carbon nanotubes in Portland cement, US Patent, 9085487 B2.

[13] LUDVIG, P., CALIXTO, J. M., LADEIRA, L. O., and GASPAR, I. C. P., 2011, Using Converter Dust to Produce Low-Cost Cementitious Composites by in situ Carbon Nanotube and Nanofiber Synthesis, Materials (Basel), vol. 4, no. 12, pp. 575-584,_http:// dx.doi.org/10.3390/ma4030575.

[14] PAULA, J. N.; CALIXTO, J. M.; LADEIRA, L. O.; LUDVIG, P.; SOUZA T. C. C.; ROCHA, J. M.; MELO, A. V., 2014, Mechanical and rheological behavior of oil-well cement slurries produced with clinker containing carbon nanotubes, J. of Petroleum Sci. and Eng., 122, p. 274-279, http://dx.doi.org/10.1016/j. petrol.2014.07.020.

[15] LUDVIG, P., CALIXTO, J. M., LADEIRA, L. O., SOUZA T. C. C. and PAULA, J. N., 2017, Analysis of cementitious composites prepared with car- 
bon nanotubes and nanofibers synthesized directly on clinker and silica fume, Journal of Materials in Civil. Engineering (ASCE), v. 29, http://dx.doi. org/10.1061/(asce)mt.1943-5533.0001836.

[16] SOUZA, T.C.C., 2015, Síntese contínua e caracterização de cimento Portland fabricado com nanotubos de carbono, Master's Dissertation, Universidade Federal de Minas Gerais, Belo Horizonte, Brazil, $184 \mathrm{p}$.

[17] SOARES, P.A., 2019, Caracterização da reologia no estado fresco de pastas de cimento Portland fabricadas com nanotubos de carbono sintetizados diretamente sobre o clínquer, Master's Dissertation, Universidade Federal de Minas Gerais, Belo Horizonte, Brazil, 138 p.

[18] PAPO, A., Rheological models for cement pastes, 1988, Materials Structure, vol. 21, p. 41-46.

[19] AMERICAN SOCIETY FOR TESTING AND MATERIALS, 2015, ASTM C1753: Standard Practice for Evaluating Early Hydration of Hydraulic Cementitious Mixtures Using Thermal Measurements ASTM International, West Conshohocken, PA, USA.

[20] BENEDETTI, A.Z., 2018, Avaliação da temperatura gerada pelo calor de hidratação de pastas de cimentos Portland fabricados com nanotubos de carbono, Master's Dissertation, Universidade Federal de Minas Gerais, Belo Horizonte, Brazil, 161 p.

[21] ASSOCIAÇÃO BRASILEIRA DE NORMAS TÉCNICAS, 2003, NBR NM 65: Cimento Portland - Determinação do tempo de pega. Rio de Janeiro.

[22] KOWALD, T., TRETTIN, R., 2009, Improvement of Cementitious Binders by Multiwall Nanotubes, in Zdenêk. B. et al. (Eds.), Proceedings of the 3rd International Symposium on Nanotechnology and Construction (NICOM 2009), Prague, Czech Republic, Berlin, Heidelberg, 31 May-2 June.

[23] HU, J., GE, Z., and WANG, K., 2014, Influence of cement fineness and water-to-cement ratio on mortar early-age heat of hydration and set times, Construction and Building Materials, vol. 50, pp. 657-663, http://dx.doi.org/10.1016/j.conbuildmat.2013.10.011. 